\title{
ENVIRONMENTAL SUSTAINABLE WASTE MANAGEMENT FOR A CITY MULTI-FLOOR MANUFACTURING CLUSTER
}

doi: $\quad 10.2478 /$ czoto-2019-0059

Date of submission of the article to the Editor: 15/11/2018

Date of acceptance of the article by the Editor: 29/12/2018

Agnieszka Deja ${ }^{1}$ - orcid id: 0000-0001-5988-788X

Tygran Dzhuguryan ${ }^{2}$ - orcid id: 0000-0001-5613-9448

${ }^{1}$ Maritime University of Szczecin, Poland, a.deja@am.szczecin.pl

${ }^{2}$ Maritime University of Szczecin, Poland

Abstract: A multi-floor manufacturing in residential districts of huge city promotes decongestion of urban traffic and satisfy the population's demand for essential goods. City manufacturing and its supply chain entail several challenges related to the sustainable development of a large agglomeration. Environmental problems impose significant constraints on such manufacturing activities and production waste in the urban environment poses a real problem that needs to be addressed by special research. This paper discusses integrated sustainable production waste management for a city multi-floor manufacturing cluster, consisting of a group of production buildings and a supporting logistics node. In line with the theory of integrated sustainable waste management, three key components are addressed: waste management stakeholders, components of the waste management system, and the technical, environmental and legal aspects of a city multi-floor manufacturing cluster. The goal of the paper is to develop a concept for a model of environmental sustainable waste management in a city multi-floor manufacturing cluster, aimed at ensuring the system safety: human - technical facility - environment. This model can serve as a basis for the development of appropriate logistics chains for production waste management considering their hazardousness indicator. The versatility of the model will allow it to be widely used, and when its stages and working principles are embedded in the practice of city multi-floor manufacturing, proper control over the waste management process can be achieved. The application of the proposed model of integrated sustainable production waste management in the practice of the city multi-floor manufacturing clusters will contribute to the environmental sustainability of its operation.

Keywords: environmental sustainable, manufacturing, management, waste, safety.

\section{INTRODUCTION}

The development of huge cities is associated with a clear division into residential and industrial zones. The creation of such zones in the urban area is related with an attempt to resolve local environmental problems of industrial production and the 
supply chain activity (Fujita and Thisse, 2002). This approach is justified from the point of view of environmental safety of the population. However, the development of modern digital technologies in the framework of cleaner production and circular economy using closed-loop supply chains and reverse logistics has led to significant changes in the concept of industrial production (Murray et al., 2017). On the one hand, environmental safety, resource efficiency, flexibility and personalization are the basis of the concept of environmentally sustainable development of industrial production of huge cities and agglomerations within the paradigm-Industry 4.0 (Liao et al., 2017; Sarkis and Zhu, 2018). On the other hand, there are alternative models of production, located directly in the residential areas of huge cities directly on the consumer's site, which helps to reduce production costs and urban traffic (Dzhuguryan and Jóźwiak, 2016; Khorram Niaki and Nonino, 2017).

High consumer demand of the population for essential goods, environmental and transport problems of huge cities have led to the formation of a new production paradigm - city multi-floor manufacturing 4.0. This was made possible by the emergence of new information, production, construction and management technologies, miniaturization of goods and waste reduction, the use of modular lightweight technological equipment with the ability to assemble it at the customer, and changes in the quality of labor resources. (Dzhuguryan, 2012; Westkämper, 2014; Sarkis and Zhu, 2018).

The city multi-floor manufacturing clusters (CMFMC) is a group of multi-story production and non-production buildings and a supporting multi-floor logistics node, through which the main supply chain for the cluster activities is realized. The close location of the city logistic nodes of adjacent CMFMCs contributes to their integration into the city logistics cluster and multi-floor manufacturing mega-cluster (Dzhuguryan et al., 2018). The environmentally sustainable development of urban production should ensure the integrity of biological and physical natural systems due to their ability to self-healing and adaptation to changes. The assessment of the environmental sustainability of production systems is based on well-known principles and procedures that contribute to the adoption of effective technical, economic and social decisions. (Azapagic and Perdan, 2000; Sikdar, 2003; Sala et al., 2015; Kluczek, 2016). Such assessments are related to the analysis of energy sources, materials and raw materials used, technological equipment and manufacturing processes, products and waste, transport system, etc. For the CMFMC, such assessments have their own specifics, for example, in technology assessment (TA) and assessment of some elements of the transport system (Dzhuguryan and Jóźwiak, 2017, 2018).

This paper focuses on Environmental Sustainable Waste Management (ESWM) in the framework of the CMFMC. In the urban framework, such waste may be classified as municipal waste, which includes waste from household, trade and manufacturing enterprises, various institutions and organizations. In general, mixed municipal waste by origin and composition is like domestic waste. Municipal solid waste is to be sorted according to the established norms in the form of individual collection and municipal collection (Zhao et al., 2009; Pires et al., 2011; Elsaid et al., 2015). The ESWM is guided by various Life Cycle Assessment (LCA) models based on ISO 14000 standards (Kulczycka et al., 2015) and other management models, among which we will highlight the Integrated Sustainable Waste Management (ISWM) model (Anschutz 
et al., 2004; Rigamonti et al., 2016), in our opinion, as one of the most effective models for the CMFMC.

The goal of the paper is to develop the concept of the model the ESWM for the CMFMC, aimed at ensuring its effective functioning and system security: human technical object - environment.

\section{METHODOLOGY OF RESEACH}

The methodological basis for the development of the ISWM for a CMFMC is the ISWM theory, which recognizes three key components are addressed: (1) waste management stakeholders, (2) components of the waste management system, and (3) the technical, environmental, legal and other aspects (Anschutz et al., 2004).

The main role of stakeholders is related to the organization of execution of the basic requirements of the legislation in terms of safe waste management. It is necessary to highlight the CMFMC stakeholder's role, which attract experts to assess the products and goods, analysis of project documentation, technologies for their manufacturing in terms of minimizing municipal waste, identification of activities in the field of waste management, providing of the ESWM for the CMFMC. At the stage of such assessments the methods of the TA, LCA and other are used (Sala et al., 2015; Kluczek, 2016). The boundary values of these estimates determine aspects of the third key component of the ISWM theory. The CMFMC stakeholders also form a waste management strategy considering their environment and health hazard rating. The paper deals with the issues of decision-making by CMFMC stakeholders related to the placement of production facilities in the buildings of the cluster considering the nature, type of fractions, the intensity of generation of municipal waste and their environment and health hazard rating. Calculation of the municipal waste generation in the CMFMC is made based on the method of calculation the actual waste generation.

The second key component of ISWM is to consider the individual stages of waste treatment technology: (1) generation and separation (with disposal), (2) collection (packaging, certification and/or labelling), (3) transfer and transport, (4) treatment \& disposal (Anschutz et al., 2004). The first three stages of the waste treatment technology are carried out directly within the framework of the CMFMC and therefore are of the greatest interest for the study. These technological stages are considered in the framework of legislative norms that define the requirements for containers, their coloring, considering the nature and the waste fractions. At the same time, the principle of separate formation of logistics supply chains of municipal and individual waste collections was used (Zhao et al., 2009).

\section{RESULTS}

\subsection{Scenario of the ESWM for the CMFMC}

The ESWM scenario depends on the size of the CMFMC, the variety of technologies and production processes used, the data set on the volumes and characteristics of municipal and individual waste collections. The stakeholders take part in the implementation of the conceptual model of ESWM for the CMFMC. The methodological basis of the ESWM is the methods of the TA, LCA, ISWM assessment, which provide the necessary information for forecasting and management of municipal waste in the conditions of the CMFMC based on models such as Environmental Assessment of Solid Waste Systems and Technologies 
(EASEWASTE), which has been developed by the Technical University of Denmark. The overall strategy of such assessments is aimed at implementing the concepts of "zero waste" and 4R: reduce, reuse, recycle, recovery (Anschutz et al., 2004; Yoshida et al., 2007). The obtained information on the structure and fractions of municipal waste depending on the technologies and materials used in the CMFMC allows to rationally distribute technological equipment on the floors of buildings and group production by the same waste fractions, to predict the generation of municipal waste collections, to organize the management of the supply chains of waste and the fulfillment of the basic requirements of the legislation in terms of safe waste management.

\subsection{The distribution of the municipal waste sources for the CMFMC}

Location of technological equipment in the multi-floor manufacturing building is made considering its weight and overall dimensions, as well as the weight and overall dimensions of products and the nature and fractions of the solid municipal waste. Production of large-sized (heavy) products with solid and / or liquid waste is carried out mainly on the lower floors of the building. Waste-free production and production of small-sized products with gaseous waste is located mainly on the upper floors of the building.

In manufacturing buildings, cellular and technological form of production process organization is used, in which the technological equipment is placed on the floors in accordance with the family of products or workpieces. At the same time, it is advisable to group the process equipment on the floors of the building into fractions of solid waste. Minimization of solid municipal waste fractions of multi-floor manufacturing buildings reduces costs and time of their shipment and contributes to the system security: human - technical object - environment.

Another important aspect of the ESWM is the reduction of the range of municipal waste produced in the multi-floor manufacturing building. The result of this approach is the ability to group buildings into municipal waste fractions and place production facilities with greater waste generation or with a high hazardousness indicator closer to the logistics hub to reduce the time of their shipment to treatment or disposal centers.

\subsection{Daily municipal waste turnover of the logistic node for the CMFMC}

The daily municipal waste turnover of the logistic node for the CMFMC is an important indicator for waste transfer and transport. Based on previous results (Dzhuguryan and Jóźwiak, 2017; Dzhuguryan et al., 2018), it is possible to determine the daily municipal waste turnover of the logistic node for the CMFMC:

$$
\mathrm{W}_{\mathrm{W}(\mathrm{V}) . \mathrm{D}}=38400 \sum_{\mathrm{i}=1}^{\mathrm{n}} \frac{h_{i} K_{E . i} K_{O . i} K_{w . i} n_{i} \mathrm{~T}_{\mathrm{W}(\mathrm{V}) . \mathrm{i}} v_{i} \mathrm{~S}_{\mathrm{i}}\left(\mathrm{S}_{\mathrm{i}}-\varepsilon_{\mathrm{i}} \mathrm{S}_{\mathrm{E} . \mathrm{i}}\right)}{\mathrm{q}_{\mathrm{i}} \mathrm{k}_{\mathrm{C} . \mathrm{i}} \mathrm{f}_{\mathrm{i}} \mathrm{F}_{\mathrm{i}} \mathrm{S}_{\mathrm{E} . \mathrm{i}}^{2}}
$$

Where:

$\mathrm{W}_{\mathrm{W}(\mathrm{V}) . \mathrm{D}}$ - daily municipal waste turnover of the logistic node for the CMFMC, $\mathrm{t}\left(\mathrm{m}^{3}\right)$; $\mathrm{T}_{\mathrm{W}(\mathrm{V}) \cdot \mathrm{i}}$ - the rated load (volume) of IRTs in the i-th multi-floor manufacturing building, $\mathrm{t}\left(\mathrm{m}^{3}\right) ; K_{E \cdot i}-$ load factor the of freight elevators in the production processes for i-th multi-floor manufacturing building; $K_{O \cdot i}-$ the ratio of operating loss in the i-th multi- 
floor manufacturing building; $K_{W \cdot i}-$ the ratio of production waste generation in the $i$-th multi-floor manufacturing building; $\mathrm{v}_{\mathrm{i}}$ - the rate speed of the freight elevator, $\mathrm{m} / \mathrm{s} ; S_{i}-$ total area of each floor of the i-th multi-floor manufacturing, m2; $S_{E \cdot i}-$ the actual areas occupied by the freight elevator for the i-th multi-floor manufacturing, $\mathrm{m}^{2} ; \varepsilon_{i}-$ the numbers of the freight elevators for the i-th multi-floor manufacturing; $q_{i}$ - average numbers of the manufacturing cells on each floor of the i-th multi-floor manufacturing; $k_{c . i}$ - the coefficient of losses of time cycle of a work of the freight elevators in the $i$-th multi-floor building; $f_{i}$ - the interfloor distance in the i-th multi-floor building, m; $F_{i}-$ the number of production floor of the i-th manufacturing part of the building; $n$ - number of the multi-floor manufacturing buildings in the cluster; $h_{\mathrm{i}}$ - the number of work shifts (one shift $-8 \mathrm{~h}$ ) per day in the i-th multi-floor manufacturing; $n_{\mathrm{i}}$ - the numbers of the IRTs in the freight elevator for the i-th multi-floor manufacturing.

The daily municipal waste turnover of the logistic node for the CMFMC depends on the ratios of production waste generation, number of floors of manufacturing buildings, capacity of the freight elevators, internal transport, floor-by-floor differentiation of manufacturing, technological processes and operations, etc. The ratios of operating loss that are associated with the transportation of materials and components necessary for the operation and repair of technological equipment.

\subsection{Management of supply chains of municipal and individual waste}

Collection and transportation of the individual and municipal waste is carried out separately.

The individual waste collection is generated by the population and personnel of enterprises and organizations with the use of stationary containers and are delivered by specialized trucks to the points of their treatment or disposal bypassing the logistic node.

The municipal waste collection is formed in specialized Intelligent Reconfigurable Trolleys (IRTs) directly in the manufacturing enterprises and various institutions and organizations. The features of the IRT are a modular design that allows them to be quickly re-configured for various freights, and the availability of identification and monitoring device for recording and transmitting data via Wi-Fi about the parameters, dates and routes of delivery in the database of the control software, and the ability to complete from its a multi-IRT for the transportation by truck (Dzhuguryan et al., 2011). Delivery of the IRTs to enterprises and shipment of municipal waste is made through the logistics node by internal trucks, in which can be transported at the same time the IRTs with other goods, for example, finished goods. Sorting, collection and transportation of municipal waste is carried out in appropriately colored containers, which are installed in the IRTs. It is important to ensure not only the synchronization of transport operations, but also the safety of waste management in the workplace, in the logistics node and during their transportation in trucks.

Information support and management of municipal waste is based on the EASEWASTE model. Information about waste considering their hazardousness indicator is recorded on the identification and monitoring device of the IRTs and via Wi-Fi automatically enters the EASEWASTE database. For the waste management by EASEWASTE model is important of the IRTs delivery date to manufacturing enterprise for the collection appropriate waste, the estimated time of their filling, weight of waste, delivery time in the transfer zone (ground floor) of the multi-floor 
manufacturing building and logistics node of the CMFMC and further to the appropriate centers for the treatment and disposal. This considers the time of municipal waste transfer in the logistics node from small containers of the IRTs in one bigger containers (two containers) in the IRTs with one fraction (two fractions) of municipal waste, which are taken in a center for their treatment and disposal.

\section{DISCUSSION}

Scenario ESWM of the CMFMC change considering external and internal conditions. The legislative base, norms of environmental safety are changing, new needs of the population in innovative products appear, new technologies of production and processing of waste are developing, etc. These changes affect the functioning of the CMFMC and are manifested point-by-point at different times in its manufacturing facilities. It is obvious that in these conditions the role of the stakeholders in maintaining the conceptual ESWM model for the CMFMC increases. It is at the stage of maintaining the conceptual ESWM model for CMFMC that it is advisable to use the operational ESEWASTE model, which is based on the LCA methodology. At the same time, it is necessary to consider the previously adopted conceptual decisions related to the placement and grouping of technological equipment and sources of municipal waste in the multi-floor manufacturing buildings, the possibilities of the transport system and logistics node, etc.

The municipal waste generation in the CMFMC is pre-calculated based on the method of calculation the actual waste generation and specified in the analysis of the EASEWASTE database. This allows you to determine the needs for the CMFMC in containers, IRTs and specialized and freight trucks.

The separate collection of individual and municipal waste collections has its own specifics. The main treatment technologies are recycling and reuse. Some types of individual and municipal waste are incinerated and landfilled. Municipal waste does not have mixed domestic and food waste. In the case of mixed domestic and food waste generation in the manufacturing enterprises, they are collected in the form of individual waste collections.

If the waste fractions coincide, it is possible in principle to add individual waste collections to municipal ones. However, municipal waste that are in IRTs are weighed on arrival at the logistics node, and the cost of payment for their removal from the manufacturing enterprise depends on their weight. Due to the large number of transfer operations, the cost of exporting municipal waste collections is higher than the cost of exporting individual waste collections. Therefore, the adding of individual waste collections to municipal waste is not beneficial. On the other hand, adding municipal waste collections to individual waste collections, even if their fractions coincide, is prohibited (except for mixed domestic and food waste).

When transporting municipal waste in a truck together with other goods by the multiIRTs, it is important to ensure the safety of waste management. The multi-IRTs package must ensure the safe handling of waste in accordance with environmental and health hazard rating and the appropriate safety instructions (Lithner et al., 2011; Wahlström et al., 2016). Information support for such a secure configuration of the multi-IRTs can be read from the identification and monitoring device of the IRTs or from the EASEWASTE database. The main provisions of the waste safe handling for the CMFMC include the following activities: organization and control of processes of the technological cycle; processes for the disposal of hazardous waste; oversight of 
transboundary movements of wastes, places of their disposal; information support of the processes of hazardous waste management.

\section{CONCLUSION}

The article presents the concept of the model ESWM for the CM FMC, the analysis of the key components of individual and municipal waste management cluster based on the theory of ISWM, which allows:

1. To articulate the role of the CMFMC stakeholders and methodology of the TA and LCA in the implementation and maintenance of conceptual model ESWM at the stages of formation, development and transformation of the cluster.

2. To rationally distribute and group the sources of municipal waste in the multifloor manufacturing buildings, which reduces the cost and time of shipment of waste to treatment or disposal centers.

3. To evaluate of the municipal waste generation in the CMFMC to identify the need for funds to implement the stages of the waste processing process cycle within the cluster (collection, transfer and transport).

4. To organize the management of supply chains of individual and municipal waste based on the EASEWASTE model and information on the characteristics of municipal waste, the timing of the technological steps, which is recorded on the identification and monitoring device of the IRTs and through Wi-Fi is automatically entered into the EASEWASTE database.

5. To formulate the main provisions of municipal waste management at the initial stages of the technological cycle of their treatment (generation and separation, collection, transfer and transport), because the delivery of waste to the logistics node through IRTs is made in conjunction with finished products and goods.

\section{REFERENCES}

Anschutz, J., IJgosse, J., Scheinberg, A., 2004. Putting Integrated Sustainable Waste Management into Practice Using the ISWM Assessment Methodology: ISWM Methodology as Applied in the UWEP Plus Programme (2001-2003), WASTE: Gouda, The Netherlands.

Azapagic, A., Perdan, S., 2000. Indicators of sustainable development for industry: a general framework, Process Saf Environ Prot 78(4), 243-261.

Dzhuguryan T., 2012. Design Features of Flexible Manufacturing Modules in Frame Construction, Zeszyty Naukowe Politechniki Rzeszowskiej. Mechanika, Oficyna Wydawnicza Politechniki Rzeszowskiej, z. 84[284], 1, 21-25.

Dzhuguryan T., Jóźwiak Z., 2016. Infrastructure for Multi-Floor Virtual Enterprises System, Systemy wspomagania w inżynierii produkcji, P.A. Nowa S.A. Gliwice, 3(15), 70-78.

Dzhuguryan, T., Jóźwiak, Z., 2017. Specific Approach to Assessment of Technologies for Multi-Floor Manufacturing System, Autobusy: technika, eksploatacja, systemy transportowe, nr 6, 1656-1659.

Dzhuguryan, T., Jóźwiak, Z., 2018. Specific Approach to Select of Freight Elevators for Multi-Floor Manufacturing, Autobusy: technika, eksploatacja, systemy transportowe, nr 12, 1059-1062. 
Dzhuguryan, T., Jóźwiak, Z., Deja, A., Semenova, A., 2018. Infrastructure and Functions of a City Logistics Node for Multi-Floor Manufacturing Cluster, $8^{\text {th }}$ International Scientific Conference CMDTUR 2018, Žilina, Slovakia, 34.

Dzhuguryan, T., Wiśnicki, B., Dudek, T., 2018. Concept of Intelligent Reconfigurable Trolleys for City Multi-Floor Manufacturing and Logistics System, $8^{\text {th }}$ Carpathian Logistics Congress, Prague, Czech Republic.

Elsaid, S., Aghezzaf, E-H., 2015. A framework for sustainable waste management: challenges and opportunities, Manag Res Rev 38(10),1086-1097.

Fujita, M., Thisse, J.-F., 2002. Economics of Agglomeration: Cities, Industrial Localization, and Globalization, Cambridge, Massachusetts: Cambridge University Press.

Khorram Niaki, M., Nonino, F., 2017. Additive manufacturing management: a review and future research agenda. International Journal of Production Research, 55(5), 1419-1439.

Kluczek, A., 2016. Application of Multi-criteria Approach for Sustainability Assessment of Manufacturing Processes. Management and Production Engineering Review, 7(3), 62-78.

Kulczycka, J., Lelek, Ł., Lewandowska, A., Zarębska. J., 2015. Life Cycle Assessment of Municipal Solid Waste Management - Comparison of Results Using Different LCA Models. Pol. J. Environ. Stud. 24, (1), 125-140.

Lithner, D., Larsson, A., Dave, G., 2011. Environmental and health hazard rating, and assessment of plastic polymers based on chemical composition, Sci. Total Environ. 409, 3309-3324.

Pires, A., Martinho, G., Chang, N-B., 2011. Solid waste management in European countries: a review of systems analysis techniques, J Environ Manag 92(4),10331050.

Rigamonti, L., Sterpi, I., Grosso, M., 2016. Integrated municipal waste management systems: An indicator to assess their environmental and economic sustainability, Ecol. Indic., 60, 1-7.

Sala, S., Ciuffo, B., Nijkamp, P., 2015. A systemic framework for sustainability assessment. Ecological Economics, 119, 314-325.

Sarkis, J., Zhu, Q., 2018. Environmental sustainability and production: taking the road less travelled, International Journal of Production Research, 56:1-2, 743-759.

Sikdar, SK., 2003. Sustainable development and sustainability metrics, AIChE J 49(8),1928-1932.

Wahlström, M., Laine-Ylijoki, J., Wik, O., Oberender, A., Hjelmar, O., 2016. Hazardous Waste Classification: Amendments to the European Waste Classification Regulation - What Do They Mean and What Are the Consequences? Nordic Council of Ministers.

Westkämper E., 2014. Towards the Re-Industrialization of Europe. A Concept for Manufacturing for 2030, Berlin: Springer, Germany.

Yoshida, H., Shimamura, K., Aizawa, H., 2007. 3R strategies for the establishment of an international sound material-cycle society, J Mater Cycles Waste Manag 9(2), 101-111.

Zhao, Y., Wang, HT., Lu, WJ., 2009. Life-cycle assessment of the municipal solid waste management system, in Hangzhou, China (EASEWASTE). Waste Management Research, 27(4), 399-406. 